\title{
Endothelin (ET)-1 and ET-3 inhibit estrogen and cAMP production by rat granulosa cells in vitro
}

\author{
A E Calogero, N Burrello and A M Ossino \\ Division of Andrology, Department of Internal Medicine, University of Catania, 95123 Catania, Italy \\ (Requests for offprints should be addressed to A E Calogero at Istituto di Medicina Interna e Specialità Internistiche, Ospedale Garibaldi, Piazza S.M. di Gesù, \\ 95123 Catania, Italy)
}

\begin{abstract}
Endothelin (ET)-1 and ET-3, two peptides with a potent vasoconstrictive property, produce a variety of biological effects in different tissues by acting through two different receptors, the ET-1 selective $\mathrm{ET}_{\mathrm{A}}$ receptor and the nonselective $\mathrm{ET}_{\mathrm{B}}$ receptor. An increasing body of literature suggests that ET-1 acts as a paracrine/autocrine regulator of ovarian function. Indeed, $\mathrm{ET}_{\mathrm{B}}$ receptors have been identified in rat granulosa cells and ET-1 is a potent inhibitor of progesterone production. In contrast, inconsistent data have been reported about the role of ET-1 on estrogen production and the effects of ET-3 are not known. Therefore, the present study was undertaken to evaluate the effects of ET-1 and ET-3 on estrogen and cAMP production, and the receptor type involved. Given that prostanoids modulate ovarian steroidogenesis and that many actions of ETs are mediated by these compounds, we also evaluated whether the effects of ETs on estrogen and cAMP production might be prostanoid-mediated. ET-1, ET-3, and safarotoxin-S6c (SFX-S6c), a selective $\mathrm{ET}_{\mathrm{B}}$ receptor agonist, inhibited basal estrogen production by granulosa cells obtained from immature, estrogen-primed female rats, in a concentration-dependent manner. All three peptides were also capable of inhibiting the production of estrogen stimulated by a half-maximal $(1 \mathrm{mIU} / \mathrm{ml})$
\end{abstract}

and a maximally stimulatory $(3 \mathrm{mIU} / \mathrm{ml})$ concentration of FSH. ET-1 and ET-3 dose-dependently suppressed basal and FSH $(1 \mathrm{mIU} / \mathrm{ml})$-stimulated cAMP production. ET-3 and SFX-S6c were significantly more potent than ET-1 in suppressing estrogen production, suggesting that this effect was not mediated by the $\mathrm{ET}_{\mathrm{A}}$ receptor. Indeed, $\mathrm{BQ}-123$, a selective $\mathrm{ET}_{\mathrm{A}}$ receptor antagonist, did not influence the inhibitory effects of ET-1 and ET-3 on basal and FSH-stimulated estrogen release. To determine a possible involvement of prostanoids, we evaluated the effects of maximally effective concentrations of ET-1 and ET-3 on estrogen and cAMP production in the presence of indomethacin, a prostanoid synthesis inhibitor. This compound did not have any effect on the suppressive effects of ETs on basal or FSH $(1 \mathrm{mIU} / \mathrm{ml})$-stimulated estrogen or cAMP production.

In conclusion, ET-1 and ET-3 were able to inhibit estrogen and cAMP production by rat granulosa cells, indicating that the inhibitory effects of ETs on ovarian steroidogenesis are not limited to progesterone biosynthesis. This effect does not appear to be mediated by prostanoids or by the classical $\mathrm{ET}_{\mathrm{A}}$ and $\mathrm{ET}_{\mathrm{B}}$ receptors, at least under these experimental conditions.

Journal of Endocrinology (1998) 157, 209-215

\section{Introduction}

Endothelins (ETs), a family of 21-amino acid peptides, are present in three different isoforms coded by separate genes, endothelin (ET)-1, ET-2, and ET-3 respectively (Inoue et al. 1989). They were first isolated from endothelial cells by virtue of their potent vasoconstrictor properties (Yanagisawa et al. 1988). However, it soon became apparent that these peptides produce a variety of biological effects (Masaki 1993) mediated by two distinct G-proteincoupled receptors named $\mathrm{ET}_{\mathrm{A}}$ and $\mathrm{ET}_{\mathrm{B}}$ (Watanabe et al. 1989). Although these receptors show about $63 \%$ amino acid homology, they bind ET isopeptides and analogs with different affinities. $\mathrm{ET}_{\mathrm{A}}$ has a more elevated affinity for ET-1 than for ET-3 and $\mathrm{ET}_{\mathrm{A}}$-mediated cellular effects are blocked by the peptide antagonist, BQ-123. Conversely, the $\mathrm{ET}_{\mathrm{B}}$ receptor binds $\mathrm{ET}-1$ and $\mathrm{ET}-3$ with equal affinity and it is selectively activated by safarotoxin-S6c (SFX-S6c) (Bax \& Saxena 1994).

A number of studies have shown that ETs participate in the regulation of the endocrine system (Hirai et al. 1991, Masaki 1993, Calogero et al. 1994) and recent evidence suggests that ETs may act as paracrine/autocrine regulators of ovarian endocrine function. Indeed, it has been shown that ETs are able to inhibit basal and gonadotropinstimulated progesterone production, cAMP accumulation, and morphological transformation of granulosa cells in culture (Iwai et al. 1991, Flores et al. 1992, Tedeschi et al. 1992, 1994, Kamada et al. 1993). Although the effects of ETs on progesterone production are well known, 
inconsistent data have been reported on the role of ET-1 in estrogen production by granulosa cells (Kamada et al. 1992, Tedeschi et al. 1994), and the effects of ET-3 are not known. Hence, this study was undertaken to evaluate the role of ET-1 and ET-3 on estrogen and cAMP production by granulosa cells obtained from immature, estrogenprimed rats, and to identify the ET receptor which mediates this effect. In consideration of the fact that prostanoids exert inhibitory effects on ovarian steroidogenesis (Behrman \& Caldwell 1986) and that a number of ET-1 actions are prostanoid-mediated (Anderson et al. 1995, Howarth et al. 1995), we also evaluated whether indomethacin, a prostanoid synthesis inhibitor, modulates the effects of ET-1 or ET-3 on estrogen or cAMP production.

\section{Materials and Methods}

\section{Rat granulosa cell culture}

Rat granulosa cells were cultured as previously reported (Jia \& Hsueh 1986, Calogero et al. 1996). Briefly, intact female immature (25 days old) Sprague-Dawley rats (Charles River, Calco, CO, Italy) were implanted subcutaneously with a $10 \mathrm{~mm}$ Silastic brand capsule (Dow Corning, Midland, MI, USA) filled with diethylstilbestrol (DES; Sigma Chemical Co., St Louis, MO, USA). Four days after implantation, rats were sacrificed by cervical dislocation, and ovaries were removed for granulosa cell collection. Ovaries were decapsulated, follicles were punctured with 27-gauge hypodermic needles, and granulosa cells were carefully expressed into McCoy's 5 a medium (Life Technologies, Paisley, Strathclyde, UK) to make a single cell suspension that was used for control and experimental cultures. An aliquot was diluted with trypan blue stain, and viable cells were counted with a hemocytometer. Cells were plated into $16 \mathrm{~mm}, 24-$ multiwell plates (Corning, Milan, Italy) at a density of 50000 viable cells/well $/ 0.5 \mathrm{ml}$ at $37{ }^{\circ} \mathrm{C}$ in a humidified, 95\% air-5\% $\mathrm{CO}_{2}$ water-jacketed incubator in the presence of graded concentrations of ET-1 (Peninsula Laboratories Inc., Belmont, CA, USA), ET-3 (Peninsula), SFX-S6c (Sigma), BQ-123 (Peninsula), and/or indomethacin (Sigma) for six days. BQ-123 or indomethacin were added simultaneously with ETs. Time-course studies showed that maximal estrogen production in response to increasing concentrations of follicle-stimulating hormone (FSH) (NIDDK hFSH B-1, AFP-8792B) was achieved after six days of incubation (Calogero et al. 1996). Each treatment was applied in triplicate within each experiment and each experiment was replicated at least three times. Incubation was carried out using McCoy's 5a medium supplemented with $2 \mathrm{mM}$ L-glutamine (Life Technologies), $200 \mathrm{U} / \mathrm{ml}$ penicillin, $200 \mu \mathrm{g} / \mathrm{ml}$ streptomycin sulfate, $0.5 \mu \mathrm{g} / \mathrm{ml}$ fungizone (Life Technologies), $10^{-6} \mathrm{M}$ androstenedione (Sigma), $10^{-7} \mathrm{M}$ DES (Sigma), $37.5 \mathrm{ng} / \mathrm{ml}$ human chorionic gonadotropin (hCG, CR-127; NIDDK,
Bethesda, MD, USA), $35 \mu \mathrm{g} / \mathrm{ml}$ methyl-isobutylxanthine (MIX; Sigma), and $1.25 \mu \mathrm{g} / \mathrm{ml}$ insulin (Eli Lilly Co., Indianapolis, IN, USA). DES and MIX were added to enhance the sensitivity of granulosa cells to FSH (Jia \& Hsueh 1986). At the end of the culture period, medium samples were frozen at $-20{ }^{\circ} \mathrm{C}$ until assayed for estrogen.

\section{Estrogen radioimmunoassay}

The concentration of estrogen in the incubation medium was measured directly, without extraction, by radioimmunoassay, as previously reported (Calogero et al. 1996). Aliquots $(200 \mu \mathrm{l})$ of medium, diluted 1:40-1:100, or standard solutions were incubated with $100 \mu \mathrm{l}$ antiserum (final dilution 1:10 000), and $100 \mu \mathrm{l}\left[{ }^{3} \mathrm{H}\right]$ estradiol $\left(\mathrm{E}_{2}\right)$ (about 9000 c.p.m.) at $4{ }^{\circ} \mathrm{C}$ for $18-20$ h. Ice-cold charcoal-dextran was then added to achieve separation of bound from free labeled hormone. Tubes were centrifuged at $1500 \mathrm{~g}$ at $4{ }^{\circ} \mathrm{C}$ for $11 \mathrm{~min}$, the supernatants were collected and counted in a $\beta$-counter after the addition of scintillation fluid. The anti-estrogen serum (RD/94/84; Analytical Antibodies, Segrate, MI, Italy) bound $40 \cdot 7 \pm 2 \cdot 5 \% \quad(n=11)$ of $\left[{ }^{3} \mathrm{H}\right] \mathrm{E}_{2}$. Non-specific binding was $3 \cdot 1 \pm 0 \cdot 4 \%$. The intra- and interassay coefficients of variation were $3 \cdot 6 \pm 0 \cdot 3 \%$ and $13 \cdot 8 \%$ respectively.

\section{cAMP measurement}

At the end of the incubation, the medium was collected for estrogen measurements and $0.5 \mathrm{ml}$ ice-cold ethanol (90\%) was added to each well. The plate was placed at $-20{ }^{\circ} \mathrm{C}$ for $30 \mathrm{~min}$ and subsequently at $4{ }^{\circ} \mathrm{C}$ for 60 $90 \mathrm{~min}$. Thereafter, each sample was collected and centrifuged in a microfuge, the supernatant collected, dried, and stored at $-20{ }^{\circ} \mathrm{C}$ until the day of the RIA. cAMP was measured by RIA using a commercially available kit (Amersham International plc, Amersham, Bucks, UK). cAMP antiserum bound $59 \cdot 8 \pm 2 \cdot 8 \%(n=2)$ of ${ }^{125}$ I-cAMP (about 7000 c.p.m. $/ 100 \mu \mathrm{l})$. The detection limit $\left(\mathrm{ED}_{90}\right)$ of the assay was $19.6 \mathrm{fmol} /$ tube $(49 \cdot 0 \mathrm{fmol} /$ well $)$. The intraand interassay coefficients of variation were $1 \cdot 3 \pm 0 \cdot 3 \%$ and $5 \cdot 7 \%$ respectively.

\section{Data analysis}

Results, reported as means \pm s.E.M. throughout the study, are expressed as percentage of basal estrogen production. Statistical evaluation was performed by analysis of variance (ANOVA) followed by Duncan's multiple range test. The effects of ET-1, ET-3, or SFX-S6c on basal and FSHstimulated estrogen dose-response curves were analyzed applying the four parameter logistic equation; a computer program, 'Allfit', was employed for the computation (DeLean et al. 1978). Significance was accepted at a $P$ value below $0 \cdot 05$. 


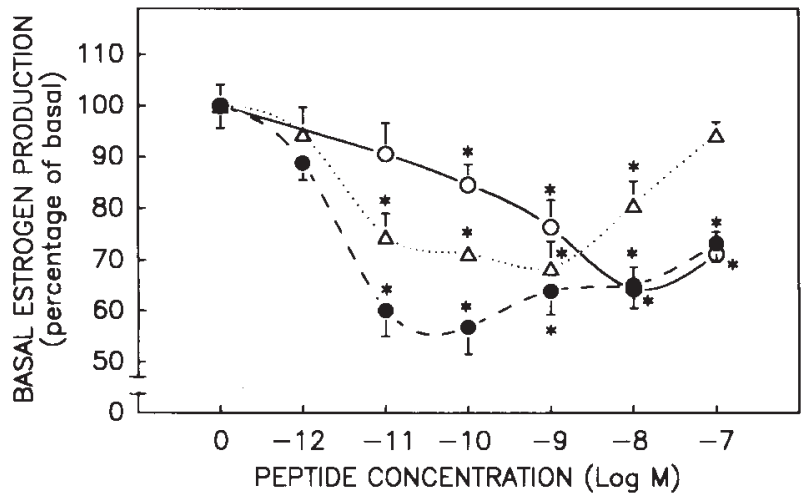

Figure 1 Effects of graded concentrations of ET-1 $(\bigcirc)$, ET-3 and SFX-S6c, a selective $\mathrm{ET}_{\mathrm{B}}$ receptor agonist $(\triangle)$, on basal estrogen production by rat granulosa cells. Results (means \pm S.E.M.) are expressed as percentage of estrogen accumulation by granulosa cells incubated without any test substance for six days. Each treatment was applied in triplicate in each of at least three different experiments. ${ }^{\star} P<0 \cdot 05$ vs concentration zero.

\section{Results}

Basal estrogen accumulation over six days was $1 \cdot 25 \pm 0 \cdot 04 \mathrm{ng} /$ well. ET-1, ET-3, and SFX-S6c suppressed basal estrogen production in a concentrationdependent fashion $(P<0 \cdot 001$, one-way ANOVA) (Fig. 1). ET-3 and the $\mathrm{ET}_{\mathrm{B}}$ receptor activator SFX-S6c were more potent than ET-1. Indeed, $10^{-11} \mathrm{M}$ was the lowest effective concentration tested, whereas it was $10^{-10} \mathrm{M}$ for ET-1. Accordingly, the half-maximal inhibitory concentrations $\left(\mathrm{IC}_{50} \mathrm{~s}\right)$ of ET-3 and SFX-S6c were significantly lower than that of ET-1 and not statistically different from each other $(P<0 \cdot 05$; see Table 1$)$.

FSH stimulated the production of estrogen by about 7to 8 -fold at a concentration of $1 \mathrm{mIU} / \mathrm{ml}$ (half maximal) and by about 16- to 17-fold at a concentration of $3 \mathrm{mIU} /$ $\mathrm{ml}$ (maximally effective). ET-1, ET-3, and SFX-S6c were able to inhibit the stimulation produced by 1 and $3 \mathrm{mIU} /$ $\mathrm{ml} \mathrm{FSH}$ in a concentration-dependent fashion $(P<0 \cdot 005$, one-way ANOVA) (Fig. 2). Their lowest effective concentration was about $10^{-11} \mathrm{M}$, whereas that of ET-1 was about 10 -fold higher. Similar to basal estrogen production, the $\mathrm{IC}_{50} \mathrm{~s}$ of ET-3 and SFX-S6c were significantly lower

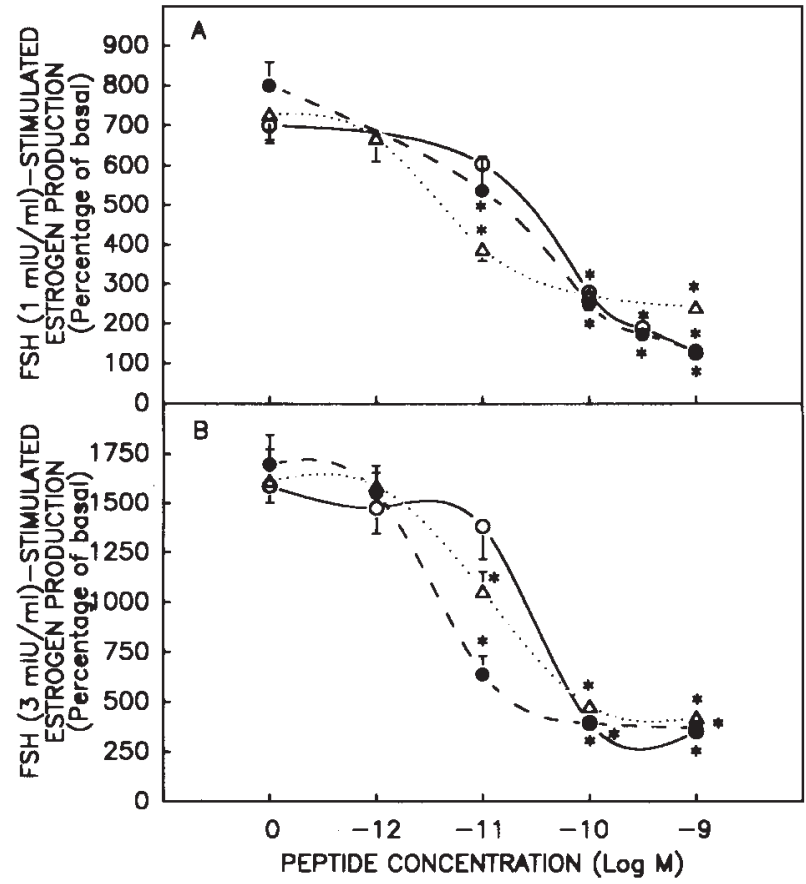

Figure 2 Effects of graded concentrations of ET-1 $(\bigcirc)$, ET-3 $(\mathbf{O})$, and SFX-S6c, a selective $\mathrm{ET}_{\mathrm{B}}$ receptor agonist $(\triangle)$, on estrogen production by rat granulosa cells exposed to a half-maximal (A) and a maximally (B) stimulatory concentration of FSH. Results (means \pm S.E.M.) are expressed as percentage of estrogen accumulation by granulosa cells incubated without any test substance for six days. Each treatment was applied in triplicate in each of at least three different experiments. ${ }^{*} P<0.05$ vs concentration zero.

than that of ET-1 and not statistically different from each other $(P<0 \cdot 05$; see Table 1$)$.

Basal intracellular cAMP content was $82 \cdot 4 \pm 7 \cdot 2 \mathrm{fmol} /$ well. ET-1 and ET-3 inhibited, in a concentrationdependent manner, the intracellular content of cAMP both in basal conditions and in response to $1 \mathrm{mIU} / \mathrm{ml} \mathrm{FSH}$ (Table 2). Both peptides were equipotent in suppressing basal and FSH-stimulated cAMP accumulation and, at the highest concentration tested $\left(10^{-9} \mathrm{M}\right)$, they were able to overcome completely the stimulation produced by FSH $(1 \mathrm{mIU} / \mathrm{ml})$. Overall, the suppressive effect of ET-1 and

Table 1 Half maximal inhibitory concentrations $\left(\mathrm{IC}_{50}\right)$ of ET-1, ET-3, and SFX-S6c on basal and $\mathrm{FSH}$-stimulated estrogen production by rat granulosa cells incubated for six days. Results are means \pm S.E.M.

Basal

$\mathrm{FSH} 1 \mathrm{mlU} / \mathrm{ml}$

$\mathrm{FSH} 3 \mathrm{mIU} / \mathrm{ml}$

\begin{tabular}{|c|c|c|}
\hline ET-1 (pM) & ET-3 (pM) & SFX-S6c (pM) \\
\hline $107 \cdot 5 \pm 20 \cdot 2$ & $1 \cdot 3 \pm 0 \cdot 6^{*}$ & $2 \cdot 9 \pm 2 \cdot 0^{*}$ \\
\hline $50 \cdot 0 \pm 10 \cdot 0$ & $19 \cdot 0 \pm 5 \cdot 0^{*}$ & $5 \cdot 0 \pm 2 \cdot 0^{*}$ \\
\hline $23 \cdot 0 \pm 3 \cdot 0$ & $3 \cdot 8 \pm 0 \cdot 6^{*}$ & $11 \cdot 0 \pm 1 \cdot 2^{*}$ \\
\hline
\end{tabular}

${ }^{*} P<0 \cdot 05$ vs $\mathrm{IC}_{50}$ of ET- 1. 
Table 2 Concentration-dependent effects of ET-1 and ET-3 on the intracellular CAMP content of rat granulosa cells cultured under basal or FSH $(1 \mathrm{mIU} / \mathrm{ml})$-stimulated conditions. Results (means \pm S.E.M.) are expressed as a percentage of cAMP accumulation in granulosa cells incuabated without any test substance for six days. Each treatment was replicated three times in each of five different experiments

ET-1 ET-3

Endothelin
Basal
0
$10^{-10} \mathrm{M}$
$10^{-9} \mathrm{M}$
$10^{-8} \mathrm{M}$

$100 \cdot 0 \pm 5 \cdot 8$

$91 \cdot 0 \pm 5 \cdot 1$

$84 \cdot 5 \pm 6 \cdot 4^{\mathrm{a}}$

$81 \cdot 1 \pm 4 \cdot 5^{\mathrm{a}}$

$\mathrm{FSH}(1 \mathrm{mIU} / \mathrm{ml})$

${ }^{0} 0^{-11} \mathrm{M}$

$10^{-10} \mathrm{M}$

$10^{-9} \mathrm{M}$
$237 \cdot 5 \pm 18 \cdot 6$

$201 \cdot 6 \pm 13 \cdot 1$

$150 \cdot 9 \pm 16 \cdot 5^{\mathrm{a}, \mathrm{c}}$

$114 \cdot 2 \pm 10 \cdot 4^{\mathrm{a}, \mathrm{c}}$

$$
\begin{aligned}
100 \cdot 0 & \pm 5 \cdot 8 \\
94 \cdot 6 & \pm 6 \cdot 9 \\
70 \cdot 4 & \pm 6 \cdot 3^{\mathrm{a}, \mathrm{b}} \\
67 \cdot 3 & \pm 6 \cdot 4^{\mathrm{a}, \mathrm{b}} \\
& \\
237 \cdot 5 & \pm 18 \cdot 6 \\
197 \cdot 1 & \pm 17 \cdot 8 \\
164 \cdot 9 & \pm 20 \cdot 4^{\mathrm{a}, \mathrm{c}} \\
102 \cdot 8 & \pm 10 \cdot 2^{\mathrm{a}, \mathrm{c}}
\end{aligned}
$$

a $P<0.05$ vs concentration zero; ${ }^{b} P<0.05$ vs concentration $10^{-10} \mathrm{M}$; ${ }^{c} P<0.05$ vs concentration $10^{-11} \mathrm{M}$.

ET-3 on intracellular cAMP content reached statistical significance at concentrations higher than those required to suppress estrogen release.

We evaluated whether the selective $\mathrm{ET}_{\mathrm{A}}$ receptor antagonist, BQ-123, could antagonize the inhibitory effects of ET-1 or ET-3 on basal or FSH-stimulated estrogen production. The results of these experiments showed that BQ-123 did not have any effect on ET-1- or ET-3suppressed basal or FSH-stimulated estrogen production (Fig. 3), thus ruling out the involvement of $\mathrm{ET}_{\mathrm{A}}$ receptors. To evaluate a possible involvement of prostanoids, we tested the effects of maximally effective concentrations of ET-1 and ET-3 on estrogen and cAMP production in the presence of indomethacin, a cyclooxygenase inhibitor. Indomethacin, employed at concentrations of $10^{-7}$ and $10^{-6} \mathrm{M}$, did not modify the suppressive effects of either peptide on basal or FSH (1 $\mathrm{mIU} / \mathrm{ml})$-stimulated estrogen and cAMP production (Fig. 4).

\section{Discussion}

Experimental evidence suggests that ETs are auto/ paracrine regulators of ovarian function. First, immunoreactive ET-1 is abundant in ovarian follicular fluid (Iwai et al. 1991, Magini et al. 1996) where it is partly released from granulosa cells (Iwai et al. 1991, Kamada et al. 1993). Secondly, ET receptors are localized in granulosa cells. Human luteal-granulosa cells express mainly $\mathrm{ET}_{\mathrm{A}}$ receptors (Kamada et al. 1995, Mancina et al. 1997), whereas porcine and rat granulosa cells express almost exclusively $\mathrm{ET}_{\mathrm{B}}$ receptors (Kamada et al. 1992, Iwai et al. 1993, Tedeschi et al. 1994). However, a more recent study showed that cultured porcine granulosa cells express the
$\mathrm{ET}_{\mathrm{A}}$ receptor, because ET-1 was more potent than ET-3 in displacing the binding of labelled ET-1 in a radioreceptor assay (Flores et al. 1995). Thirdly, ETs promote rat ovarian DNA polymerase activity (Usuki et al. 1991) and porcine granulosa cell proliferation (Iwai et al. 1991). Lastly, many studies have consistently reported that ET-1, ET-2, and ET-3 suppress the production of progesterone and cAMP basally and following stimulation with gonadotropins (Iwai et al. 1991, Flores et al. 1992, Kamada et al. 1992, 1993, Tedeschi et al. 1992, 1994).

The findings of the present study showed that ET-1 and ET-3 are also able to suppress the production of estrogen and cAMP from rat granulosa cells both basally and in response to FSH. This inhibition does not seem related to deleterious effects of ETs on cell attachment or survival in culture since it has been shown that ETs do not have cytotoxic effects on granulosa cells (Tedeschi et al. 1992, 1994, Hurwitz et al. 1992). To our knowledge, only two other studies have explored the effects of ETs on estrogen production and both of them tested only the effects of ET-1 (Kamada et al. 1992, Tedeschi et al. 1994); hence this is the first report showing an inhibitory effect of ET-3 on estrogen and cAMP production from rat granulosa cells. Our results are similar to those reported by Tedeschi and co-workers (1994) who showed that ET-1, at a concentration of $10^{-7} \mathrm{M}$, inhibited FSH-stimulated, but not basal, estrogen production by suppressing aromatase activity, as determined by the tritiated water method. On the other hand, Kamada et al. (1992) found that ET-1 did not have any effect on estrogen production from porcine granulosa cell cultures. The reason for this discrepancy is not known at the present time. It may relate to species differences, although no species difference has been reported for progesterone production from porcine granulosa 


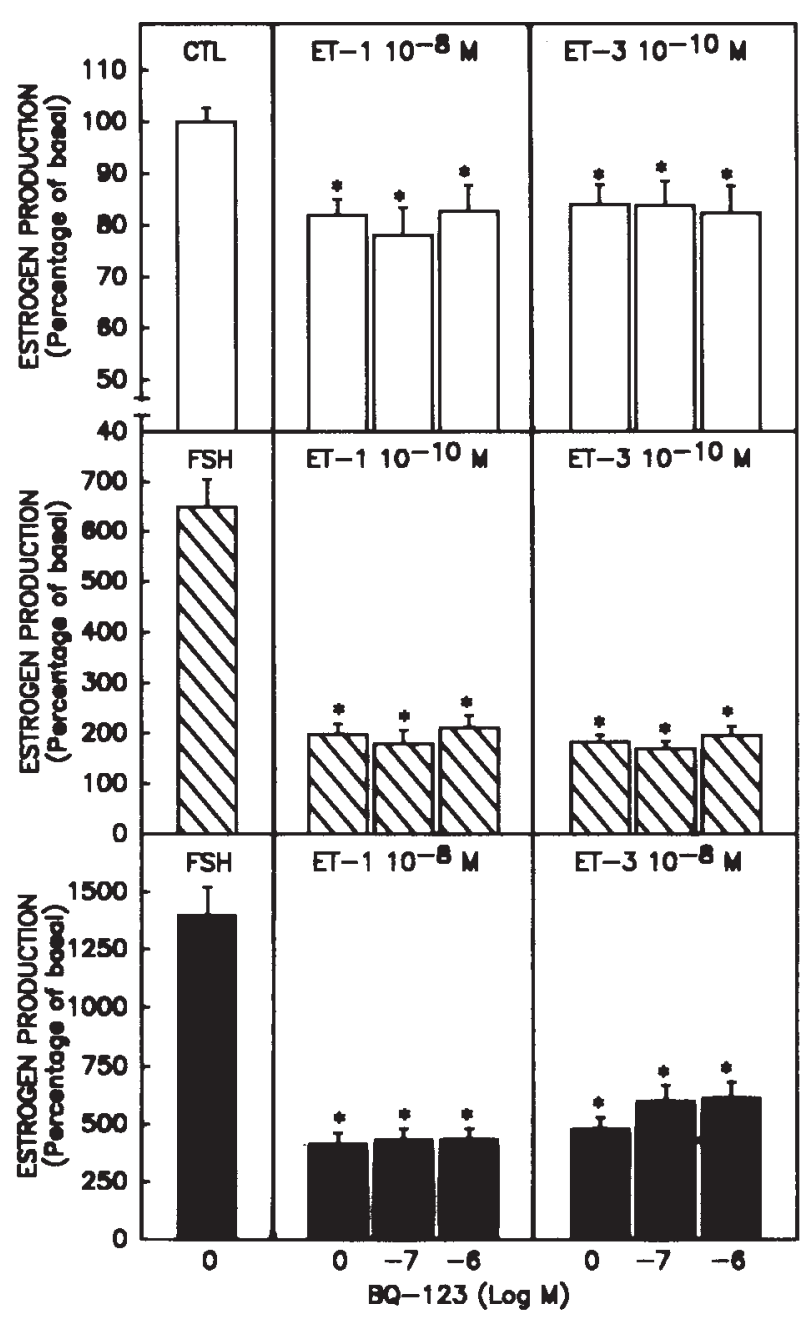

Figure 3 Effects of the selective $\mathrm{ET}_{\mathrm{A}}$ receptor antagonist, $\mathrm{BQ}-123$, on basal (upper panel), $\mathrm{FSH} 1 \mathrm{mlU} / \mathrm{ml}$ (middle panel)-stimulated, and FSH $3 \mathrm{mlU} / \mathrm{ml}$ (lower panel)-stimulated estrogen production suppressed by ET-1 or ET-3. Results (means \pm S.E.M.) are expressed as percentage of estrogen accumulation by granulosa cells incubated without any test substance for six days. Each treatment was applied in triplicate in each of at least three different experiments. ${ }^{*} P<0 \cdot 05$ vs control $(\mathrm{CTL})$.

cell cultures. We found that ET-1 was less effective than ET-3 or SFX-S6c, a selective $\mathrm{ET}_{\mathrm{B}}$ receptor agonist, in suppressing estrogen production in all experimental conditions tested, ruling out an involvement of the $\mathrm{ET}_{\mathrm{A}}$ receptor. Accordingly, the selective $\mathrm{ET}_{\mathrm{A}}$ receptor antagonist, BQ-123, was unable to antagonize the inhibitory effects of ET-1 and ET-3 on estrogen production. The greater potency of ET-3 and SFX-S6c suggests that their effects may be mediated by a non-ET $\mathrm{B}_{\mathrm{B}}$ receptor. The existence of a non-ET $\mathrm{E}_{\mathrm{B}}$ receptor-mediated effect of ET-1 has recently been reported on human airway smooth muscle cells (Goldie et al. 1995). Alternatively, it may be hypothesized that cell culture conditions may affect the function of ET receptors, as has recently been reported for human hepatic stellate cells (Pinzani et al. 1996). In this regard, Angelova et al. (1996) found at least three classes of ET binding sites in sheep choroid plexus cells. One of these is the conventional $\mathrm{ET}_{\mathrm{A}}$ receptor that mediates an increase in intracellular levels of inositol 1,4,5trisphosphate in response to ET-1. The other two have much higher binding affinity and are not coupled to the common signal transduction pathways. However, northern blot analysis showed the presence of only the $\mathrm{ET}_{\mathrm{A}}$ receptor mRNA in these cells. Therefore, it remains to be determined whether these multiple binding sites are distinct gene products, multiple affinity states of a single receptor molecule or a result of cooperative association of one site with either the ligand or with other proteins.

Since FSH stimulates aromatase activity in granulosa cells by increasing the generation of cAMP (Catt \& Pierce 1986), we evaluated whether ET-1 and ET-3 affected estrogen production by interfering with this ability of FSH. The finding that both ETs are able to suppress basal and FSH-stimulated cAMP formation suggests that their suppressive effects on estrogen accumulation are mediated by the suppressive action of ETs on the cAMP generating mechanism. However, this does not seem to be the only mechanism responsible, since estrogen production was inhibited at lower concentrations of ETs than those necessary to reduce cAMP content significantly. Indeed, ETs are able to interfere with other intracellular signaling pathways in granulosa cells (Flores et al. 1992).

It has been shown that ET-1 is able to stimulate the release of prostaglandins and thromboxanes from different cell types in a dose-dependent manner (Wu et al. 1993, Markewitz et al. 1995, Takimoto et al. 1996). Accordingly, a number of ET actions appear to be mediated by prostanoids. For example, indomethacin blunts the vasoconstriction produced by ET-1 on placental blood flow (Howarth et al. 1995). Similarly, Anderson et al. (1995) reported that the effects of ET-1 on water reabsorption in conscious dogs are enhanced by pretreatment with prostanoid biosynthesis inhibitors. In this study, we tested the hypothesis that the suppression of estrogen and cAMP production induced by ETs on granulosa cells might also be mediated by prostanoids, which per se modulate ovarian steroidogenesis (Behrman \& Caldwell 1986). However, the lack of indomethacin effects, despite the reported efficacy of the concentration range tested on ovarian prostaglandin production (Band et al. 1986, Yoshimura et al. 1988), did not support this hypothesis. In conclusion, this study shows that ET-1 and ET-3 suppressed basal and FSH-stimulated estrogen and cAMP production by rat granulosa cells, indicating that the inhibitory effects of ETs on ovarian steroidogenesis are not limited to $\mathrm{C}_{21}$ progestin biosynthesis. This effect is not mediated by prostanoids or the classical $\mathrm{ET}_{\mathrm{A}}$ or $\mathrm{ET}_{\mathrm{B}}$ receptors, suggesting the existence of a novel ET receptor with greater affinity for ET-3 than ET-1. 

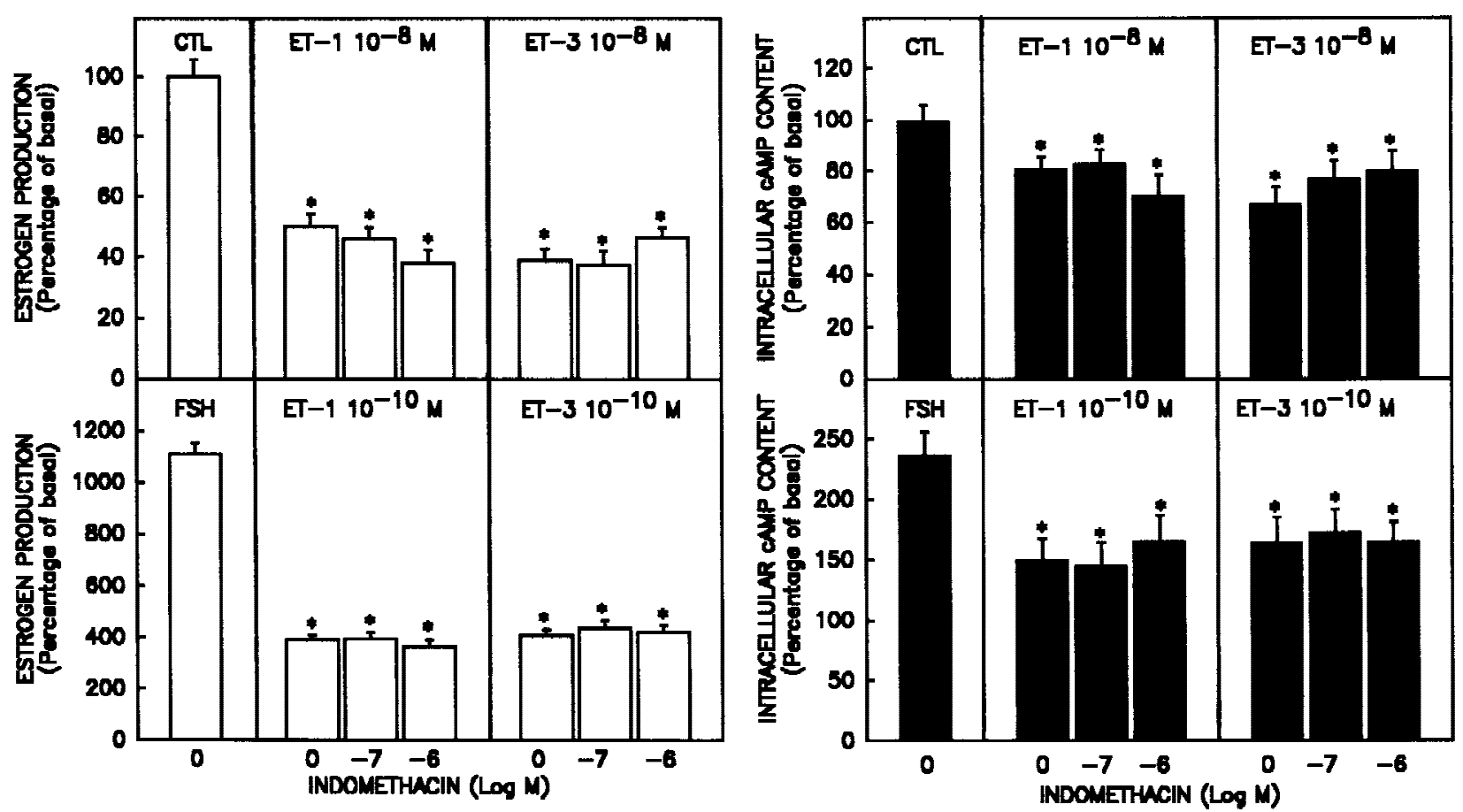

Figure 4 Effects of indomethacin, a prostanoid synthesis inhibitor, on basal (upper panels) and FSH ( $1 \mathrm{mIU} / \mathrm{ml}$ )-stimulated (lower panels) estrogen (open bars) and cAMP (solid bars) production suppressed by maximally effective concentrations of ET- 1 or ET-3. Results (means \pm S.E.M.) are expressed as percentage of estrogen or CAMP accumulation by granulosa cells incubated without any test substance for six days. Each treatment was applied in triplicate in each of at least three different experiments. ${ }^{*} P<0 \cdot 05$ vs control (CTL).

\section{Acknowledgements}

We thank Dr Raiti and Dr Parlow, National Institute of Digestive Disease and Kidney (Bethesda, MD, USA) and National Hormone and Pituitary Program (Baltimore, MD, USA) for the generous gifts of FSH (B-1, AFP8792B) and hCG (CR-127). The authors are also indebted with Mr Domenico Recupero for his excellent technical assistance. This study was supported in part by a grant from MURST, Fellowship in Internal Medicine.

\section{References}

Anderson WP, Heguillen RM \& Woods RL 1995 Intrarenal infusions of endothelin in conscious dogs: interactions with prostanoids and angiotensin II. Journal of Cardiovascular Pharmacology 26 511-517.

Angelova K, Fralish GB, Puett D \& Narayan P 1996 Identification of conventional and novel endothelin receptors in sheep chorioid plexus cells. Molecular and Cellular Biochemistry 159 65-72.

Band V, Kharbanda SM, Murugesan K \& Farooq A 1986 Prostacyclin and steroidogenesis in goat ovarian cell types in vitro. Prostaglandins 31 509-525.

Bax WA \& Saxena PR 1994 The current endothelin receptor classification: time for reconsideration? Trends in Pharmacological Science 15 379-386.

Behrman HR \& Caldwell BV 1986 Prostaglandins, thromboxanes, and leucotrienes. In Reproductive Endocrinology: Physiology, Pathophysiology and Clinical Management, edn 2, pp 154-176. Eds SSC Yen and RB Jaffe. Philadelphia: WB Saunders Co.

Calogero AE, Raiti F, Nicolosi G, Burrello N, D'Agata R \& Mantero F 1994 Effects of endothelin-1 and endothelin-3 on rat hypothalamic corticotrophin-releasing hormone and pituitary ACTH release in vitro. Journal of Endocrinology 140 419-424.

Calogero AE, Burrello N, Negri-Cesi P, Papale L, Palumbo MA, Cianci A, Sanfilippo S \& D'Agata R 1996 Effects of corticotropinreleasing hormone on ovarian estrogen production in vitro. Endocrinology 137 4161-4166.

Catt KJ \& Pierce JG 1986 Gonadotropic hormones of the adenohypophysis. In Reproductive Endocrinology: Physiology, Pathophysiology and Clinical Management, edn 2, pp 75-104. Eds SSC Yen and RB Jaffe. Philadelphia: WB Saunders Co.

DeLean A, Munson PJ \& Rodbard D 1978 Simultaneous analysis of families of sigmoidal curves: application to bioassay, radioligand assay, and physiological dose-response curves. American Journal of Physiology 235 E97-E102.

Flores JA, Quyyume S, Leong DA \& Veldhuis JD 1992 Actions of endothelin-1 on swine ovarian (granulosa) cells. Endocrinology 131 1350-1358.

Flores JA, Winters TA, Knight JW \& Veldhuis JD 1995 Nature of endothelin binding in the porcine ovary. Endocrinology 136 5014-5019.

Goldie RG, Henry PJ, Knott PG, Self GJ, Luttmann MA \& Hay DW 1995 Endothelin-1 receptor density, distribution, and function in human isolated asthmatic airways. American Journal of Respiration and Critical Care Medicine 152 1653-1658.

Hirai M, Miyabo S, Ooya E, Miyanaga K, Aoyagi N, Kimura K, Kishida S \& Nakai T 1991 Endothelin-3 stimulates the hypothalamic-pituitary-adrenal axis. Life Sciences 48 2359-2363. 
Howarth SR, Wallance P \& Wilson CA 1995 Role of thromboxane A2 in the vasoconstrictive response to endothelin-1, angiotensin II and 5-hydroxytryptamine in human placental vessels. Placenta 16 679-689.

Hurwitz A, Hernandez ER, Payne DW, Dharmarajan AN \& Adashi EY 1992 Interleukin 1 is both morphogenic and cytotoxic to cultured rat ovarian cells: obligatory role for heterologous contactindependent cell-cell interaction. Endocrinology 131 1643-1649.

Inoue A, Yanagisawa M, Kimura S, Kasuya Y, Miyauchi T, Goto K \& Masaki T 1989 The human endothelin family: three structurally and pharmacologically distinct isopeptides predicted by three separate genes. Proceedings of the National Academy of Sciences of the USA $862863-2867$.

Iwai M, Hasegawa M, Taii S, Sagawa N, Nakao K, Imura H, Nakanishi S \& Mori T 1991 Endothelins inhibit luteinization of cultured porcine granulosa cells. Endocrinology 129 1909-1914.

Iwai M, Hori S, Shigemoto R, Kanzaki H, Mori T \& Nakanishi S 1993 Localization of endothelin receptor messenger ribonucleic acid in the rat ovary and fallopian tube by in situ hybridization. Biology of Reproduction 49 675-680.

Jia X-C \& Hsueh AJW 1986 Granulosa cell aromatase bioassay for follicle-stimulating hormone: validation and application of the method. Endocrinology 119 1570-1577.

Kamada S, Kubota T, Hirata Y, Taguchi M, Eguchi S, Marumo F \& Aso T 1992 Direct effect of endothelin-1 on the granulosa cells of the porcine ovary. Journal of Endocrinology 134 59-66.

Kamada S, Kubota T, Hirata Y, Imai T, Ohta K, Taguchi M, Marumo F \& Aso T 1993 Endothelin-1 is an autocrine/paracrine regulator of porcine granulosa cells. Journal of Endocrinological Investigation 16 425-431.

Kamada S, Blackmore PF, Kubota T, Oehninger S, Asada Y, Gordon K, Hodgen GD \& Aso T 1995 The role of endothelin-1 in regulating human granulosa cell proliferation and steroidogenesis in vitro. Journal of Clinical Endocrinology and Metabolism 80 3708-3714.

Magini A, Granchi S, Orlando C, Vannelli GB, Pellegrini S, Milani S, Grappone C, De Franco R, Susini T, Forti G \& Maggi M 1996 Expression of endothelin-1 gene and protein in human granulosa cells. Journal of Clinical Endocrinology and Metabolism 81 1428-1433.

Mancina R, Barni T, Calogero AE, Filippi S, Amerini S, Peri A, Susini T, Vannelli GB, Burrello N, Forti G \& Maggi M 1997 Identification, characterization and biological activity of endothelin receptors in human ovary. Journal of Clinical Endocrinology and Metabolism 82 4122-4129.

Markewitz BA, Kohan DE \& Michael JR 1995 Endothelin-1 synthesis, receptors, and signal transduction in alveolar epithelium: evidence for an autocrine role. American Journal of Physiology 168 L192-L200.
Masaki T 1993 Endothelins. Homeostatic and compensatory actions in the circulatory and endocrine systems. Endocrine Reviews $\mathbf{1 4}$ $256-268$

Pinzani M, Milani S, De Franco R, Grappone C, Caligiuri A \& Gentilini A 1996 Endothelin-1 is overexpressed in human cirrhotic liver and exerts multiple effects on activated hepatic stellate cells. Gastroenterology 110 534-548.

Takimoto M, Oda K, Sasaki Y \& Okada T 1996 Endothelin-A receptor-mediated prostanoid secretion via autocrine and deoxyribonucleic acid synthesis via paracrine signalling in human bronchial epithelial cells. Endocrinology 137 4542-4550.

Tedeschi C, Hazum E, Kokia E, Ricciarelli E, Adashi EY \& Payne D 1992 Endothelin-1 as a luteinization inhibitor: inhibition of rat granulosa cell progesterone accumulation via selective modulation of key steroidogenic steps affecting both progesterone formation and degradation. Endocrinology 131 2476-2478.

Tedeschi C, Lohman C, Hazum E, Ittop O, Ben-Shlomo I, Resnick CE, Payne DW \& Adashi EY 1994 Rat ovarian granulosa cell as a site of endothelin reception and action: attenuation of gonadotropin-stimulated steroidogenesis via perturbation of the A-kinase signaling pathway. Biology of Reproduction 51 1058-1065.

Usuki S, Otani S, Goto K, Matsumoto H, Suzuki N, Yanagisawa M \& Masaki T 1991 Endothelin induces DNA polymerase $\alpha$ activity in ovaries of hypophysectomized estrogen-treated immature rats. Hormone and Metabolic Research 23 621-622.

Watanabe H, Miyazaki H, Kondoh M, Masuda Y, Kimura S, Yanagisawa M, Masaki T \& Murakami K 1989 Two distinct types of endothelin receptors are present in chick cardiac membranes. Biochemical and Biophysical Research Communications 161 1252-1259.

Wu T, Rieves RD, Larivee P, Logun C, Lawrence MG \& Shelhamer JH 1993 Production of eicosanoids in response to endothelin-1 and identification of specific endothelin-1 binding sites in airway epithelial cell. American Journal of Respiratory and Cellular Molecular Biology 8 282-290.

Yanagisawa M, Kurihara H, Kimura S, Tombe Y, Kobayashi M, Mitsui Y, Yazakis Y, Goto K \& Masaki T 1988 A novel potent vasoconstrictor peptide produced by vascular endothelial cells. Nature 332 411-415.

Yoshimura Y, Espey L, Hosoi Y, Adachi T, Atlas SJ, Ghodgaonkar RB, Dubin NH \& Wallach EE 1988 The effects of bradykinin on ovulation and prostaglandin production by the perfused rabbit ovary. Endocrinology 122 2540-2546.

Received 11 November 1996

Revised manuscript received 21 April 1997

Accepted 18 November 1997 